\title{
A ESSÊNCIA DA BONA FIDES E SUA RELAÇÃO COM A TEORIA DO ERRO / THE ESSENCE OF BONA FIDES AND ITS RELATION TO THE THEORY OF ERROR
}

\author{
Pietro Bonfante ${ }^{1}$ \\ Tradução: Vítor Pimentel Pereira
}

\begin{abstract}
Resumo
O presente trabalho analisa a teoria romana da bona fides e sua relação com a teoria do erro, um artigo de Pietro Bonfante, com o objetivo de demonstrar que a bona fides é um fato ético não alterado pelo direito, em qualquer relação que seja assumida.

Pressuposto de um fato ético sempre é a ação (comportamento exterior) ou o pensamento (fato psicológico): pressuposto normal da boa fé quanto à usucapião é somente um fato psicológico, o erro. Conclui que não é concebível nem uma oposição dos dois momentos e nem jamais um predomínio de um sobre o outro.
\end{abstract}

Palavras chave: Boa-fé. Fides. Bona Fides. Bonae fidei iudicia. Erro escusável. Direito Romano.

\begin{abstract}
This paper analyzes the Roman theory of bona fides and its relation to the theory of error, an article by Pietro Bonfante, with the aim of demonstrating that the bona fides is an ethical fact not changed by law in any relationship that is assumed.

Assumption of an ethical fact is always the action (external behavior) or thought (psychological fact): normal assumption of good faith as to usucapion is only a psychological fact, the error. Concludes that it is inconceivable the opposition of the two moments and neither have a prevalence of one over the other.
\end{abstract}

Keywords: Good faith. Fides. Bona Fides. Bonae iudicia fidei. Excusable error. Roman law.

\section{SUMÁRIO:}

1. Questões: Estado ético ou estado psicológico (erro). — Concepção positiva ou negativa (ausência de má fé). — Dependência ou independência da escusabilidade do erro. — Origem da discussão. — Scheurl. - Bruns.

2. Controvérsia Bruns-Wächter. - Opinião de Wächter: A boa fé é um fato do espírito, — a dúvida

\footnotetext{
${ }^{1}$ N. do T.: Pietro Bonfante (1864 - 1932), insigne romanista italiano, foi professor nas Universidades de Camerino (1888-1889), Macerata, Messina (1891-1894), Parma (1894-1901), Torino (1901-1904) e Pavia (como sucessor de Contardo Ferrini na cátedra). Em 1917, foi chamado à Faculdade de Direito de Roma, na qual ensinou até a sua morte. O texto ora traduzido foi publicado primeiramente sob o título "Essenza della Bona Fides e suo rapporto colla teorica dell'errore", no BULLETTINO DELL'ISTITUTO DI DIRITTO ROMANO, Ano VI, Fascículo II-IV, Roma, 1893. Nesta tradução, os textos originais latinos, quando demasiado longos, foram deslocados para notas de rodapé, sendo inserida no corpo do texto a tradução em vernáculo, de modo a facilitar a compreensão para o leitor brasileiro moderno. Os textos latinos curtos foram traduzidos, entre parêntesis, logo após o original.
} 
do possuidor não a exclui, desde que não seja tal a excluir a crença, — o erro sobre o qual se apóia é sinal de reconhecimento de que a vontade age com defeito (erro impróprio de Savigny), e, portanto, sua escusabilidade não importa: esta concerne somente ao título putativo.

3. Opinião de Bruns: A boa fé romana é um fato exclusivamente ético, — por conseqüência (Bruns), é necessária uma convicção absoluta, - e o erro inescusável exclui a boa fé.

4. Opinião de Pernice: A boa fé compreende tanto o elemento ético quanto o elemento intelectual; mas este último prevalece absolutamente sobre o outro nos juristas romanos, excetuado somente Pompônio, — a dúvida prejudica o possuidor, se produzida por circunstâncias concretas e demonstráveis, — qual seja a relação que intermedeia entre ela [boa fé] e o erro no pensamento dos jurisconsultos romanos, no estado atual das fontes, não se consegue estabelecer; de qualquer modo, o error iuris exclui a usucapião.

5. Minha opinião. - Premissa fundamental: a bona fides é um fato ético não alterado pelo direito, em qualquer relação que seja assumida. - Conseqüências: I. Pressuposto de um fato ético sempre é a ação (comportamento exterior) ou o pensamento (fato psicológico): pressuposto normal da boa fé quanto à usucapião é somente um fato psicológico, o erro. Não é concebível nem uma oposição dos dois momentos e nem jamais um predomínio de um sobre o outro. II. A boa fé é medida por meio da consciência popular e, para os romanos, significava ausência de má fé. III. A escusabilidade do erro não importa para a boa fé: somente na ulterior expansão da bona fides em detrimento da iusta causa usucapionis se afirma a escusabilidade do erro, mas como requisito independente da usucapião, não conectado organicamente com a boa fé de modo a fazer desta uma categoria exclusivamente jurídica ou civil.

6. Demonstração da premissa fundamental e da primeira tese. - Denominação (fides, bona fides) e expressões (fideicommissum, fiducia, etc.) significando um conceito ou uma norma ética geral: ausência de notícias a respeito de uma possível alteração jurídica do conceito ético. — Explanação essencial da bona fides na possessio bonae fidei em sentido próprio. — Expressões romanas: credere, putare, etc. — Crítica de Bruns acerca da oposição do estado ético e do estado psicológico. — Crítica de Pernice sobre o predomínio do último.

7. Demonstração da segunda tese. - Crítica de Bruns sobre o elevado grau da boa fé romana. - Crítica de Pernice sobre o excessivo encargo imposto ao juiz ao valorar a ciência e consciência do possuidor.

8. Demonstração da terceira tese. - Crítica de Bruns a respeito da influência da escusabilidade. - Crítica de Wächter acerca da separação entre o título putativo e a bona fides. Argumentos para a correlação histórica e lógica entre o exaurimento da iusta causa possidendi ou usucapionis e, por sua vez, o exsurgir da iusta causa erroris ao lado da bona fides.

1. Acerca da bona fides, independentemente do âmbito e da função que esta tenha na usucapião, revolvem-se as seguintes questões, que correspondem mais intimamente à sua essência e poderiam ser encaradas quase como questões prejudiciais: Deve-se conceber a boa fé como um estado ético ou como um estado psicológico (um erro)? Deve-se concebê- 
la positivamente, isto é, demandar uma convicção positiva e absoluta, ou negativamente, isto é, como uma mera ausência de má fé? E qual é a relação da boa fé com a doutrina do erro? Ou, em outros termos, o erro inescusável destrói a boa fé ou, em verdade, não possui nenhuma influência sobre esta?

Nossos antigos juristas definiam abertamente a bona fides como uma falsa crença, um erro: dir-se-ia agora que todos eles possuíam, portanto, um conceito psicológico daquela. Tal falsa crença era para eles, em geral, a opinio dominii.

Mas se vê em nossos dias que a boa fé não pressupõe sempre um erro. Discutem alguns textos se o erro está presente na espécie bona ou mala fides, em outros textos deve-se supor a bona fides, e, tanto em um como em outros, a categoria exclui ou parece excluir o erro, a falsa crença do possuidor. Foi esta mais atenta consideração das fontes e das categorias possíveis que levou a rechaçar o velho modo de conceber a boa fé: e pareceu que não se poderia oferecer explicações àqueles casos e exprimir realmente a essência da boa fé, a não ser considerando-a como um estado meramente ético. Foi primeiro Scheurl que enveredou por esta via. ${ }^{2}$ Quem a combateu mais a fundo e exagerou a nova tendência de modo a produzir na doutrina uma notável confusão, extraindo do conceito ético da bona fides as conseqüências mais sérias sobre o grau da boa fé e sua relação com o erro, foi Bruns.

2. Por volta de 1870, acendeu-se entre Bruns e Wächter uma ampla controvérsia, originada por um célebre processo. ${ }^{3} \mathrm{O}$ caso, em realidade, ainda que Bruns trouxesse argumentos para repetir a observação de que "freqüentemente um só caso prático dá azo a penetrar mais a fundo com o olhar em um conceito jurídico que toda uma série de especulações teóricas", não me parece que seja tão interessante e característico. Deixando de lado, contudo, o fato, refiramo-nos às doutrinas opostas de Wächter e Bruns acerca da existência da bona fides e de sua relação com o erro.

\footnotetext{
${ }^{2}$ Em um escrito sobre a doutrina da usucapião, o qual deu ensejo a outro célebre de Stintzing sobre a essência da boa fé. Cfr. Scheurl Beiträge zur Bearb. des röm R. Erl. 1854, § II, pág. 29.

${ }^{3}$ Wächter foi convocado a dar parecer sobre a causa em 1869: tornou de conhecimento público este parecer em 1870. Bruns, por volta do fim do mesmo ano, opõe-se-lhe um seu, ponto por ponto contrário àquele de Wächter. Este publicou então um escrito teórico ainda mais extenso em sustento de sua opinião: Die bona fides insbesondere bei der Ersitzung des Eigenthums. Leipzig, 1871; e Bruns, por sua vez, também respondeu com um escrito teórico: Die bona fides bei der Ersitzung, Berlim 1872, o qual antepõe-se também a seu parecer.
} 
A respeito da noção específica da bona fides, Wächter aceitava a definição de Schirmer e Windscheid, "crença de não causar lesão ao proprietário", modificando-lhe, mas não tão substancialmente, a fórmula. Mas o que lhe importa fixar é que a bona fides do possuidor apóia-se sobre uma crença, uma opinião, um fato do espírito, em suma.

Em todas as várias aplicações da bona fides a um mesmo instituto, esta é sempre igual: assim, a possessio bonae vel malae fidei é sempre a mesma, seja relativa à usucapião, à petitio hereditatis, à responsabilidade nos atos ilícitos (por exemplo, no furto). Diverso, por sua vez, pode ser o significado da bona fides nos diferentes institutos. Não se exige uma convicção absoluta do próprio direito no bonae fidei possessor (possuidor de boa fé); e uma dúvida qualquer, que não chegue a excluir aquela crença, não significa mala fides.

Mas qual é a influência que sobre a boa fé assim concebida pode ter o erro? Wächter inicia resumindo a teoria geral do erro, declarando-se, exceção feita aos termos, seguidor de Savigny. Distinguem-se duas espécies de erro: o erro que é motivo determinante de um ato (Bestimmungsgrund) e o erro que é propriamente sinal de reconhecimento, isto é, motivo pelo qual se reconhece que a vontade atua eivada de defeito (Erkentnissgrund). A primeira categoria corresponde ao erro próprio de Savigny, a segunda ao erro impróprio. Na primeira série de casos, ou seja, quando o erro é motivo determinante, este não exclui os efeitos que regularmente deveriam derivar do ato, a não ser por expressa disposição de lei: é uma proteção que a lei confere em algumas poucas relações ao errante. Mas o erro deve ser, de qualquer modo, um erro escusável: fato este que não é, ordinariamente, próprio do erro de direito. Na segunda série de casos, por outro lado, o ato é nulo per se, não produzindo efeitos, porque a vontade, requisito essencial, falta: o erro é somente indício de que, contrariamente às aparências, não se quer efetivamente. Daí se extrai que [neste último caso] a escusabilidade ou inescusabilidade do erro não importa: o ato sempre é nulo.

Ora, o erro que constitui o substrato da boa fé pertence a esta segunda categoria. Ele é indício de que não se quer cometer uma ilícita apropriação da coisa alheia: ele demonstra que, no ânimo do sujeito, não há mala fides, mas bona fides. A sua escusabilidade ou inescusabilidade não muda em nada a existência do fato. Se a lei, pois, à mera existência 
deste fato relaciona algum efeito jurídico, deve-se somente observar se o fato existe ou não. Mas pode o legislador, para que o fato da bona fides produza o efeito, exigir também que o erro seja escusável; mas não modifica o fato, nem pode modificá-lo, somente o declara insuficiente: há bona fides, ainda que sua eficácia seja condicionada à escusabilidade do erro.

Mas o direito romano, segundo Wächter, não dispôs assim sobre a bona fides do possuidor, feita abstração da boa fé que integra o título (o assim chamado título putativo). Existem textos claríssimos que não só admitem a bona fides do possuidor no caso de erro inescusável, mas também admitem a sua eficácia: excluem o furto, excluem a responsabilidade inerente ao possuidor de má fé (cf. $§ 5$ I. De us. 2, 6; L. 36 D. De a. r. d. 41, 1; L. $25 \S 6$ D. De h. p. 5, 3). Dado isto, é força inferir que a escusabilidade ou inescusabilidade do erro que constitui a bona fides não impede a usucapião.

É verdade que alguns textos generalíssimos dizem abertamente que o erro de direito não aproveita à usucapião (L. 31 pr. D. De us. 41, 3; L. $32 \S 1$ ibid.; L. 4 D. De i. et f. ign. 22, 6). Mas tal princípio, Wächter diz, refere-se exclusivamente ao título putativo no qual, quando se admitiu, desejou-se que ao menos o erro fosse um erro de fato escusável (cf. L. 11 D. Pro empt. 41, 4; L. 5 § D. Pro suo 41, 10 ; L. $44 \S 4$ D. De us. et usuc. 41, 3 e textos cit.). Quanto às leis em que se declara genericamente que a ignorância ou o erro de direito são considerados na remoção de um dano, de uma perda, mas não favorecem quando se trata de obter um ganho (L. 7; L. 8 D. De i. et f. ign. 22, 6), em primeiro lugar, elas correspondem ao erro no motivo determinante (o erro próprio), depois, como Savigny demonstrou (System III p. 344 trad. it. Scialoja pág. 444), o critério enunciado por aquelas leis deve ser rechaçado, porque falso em sua generalidade como tantos princípios gerais expressos pelos romanos e como na mesma matéria o princípio errantis nulla voluntas est (“aquele que erra não tem vontade").

3. De tais idéias diverge absolutamente Bruns. Ele inicia colocando uma antítese em geral entre dois conceitos da boa fé. A boa fé se pode conceber ou sob um ponto de vista psicológico, e, em tal caso, diz-se que ela é uma convicção, uma opinião, uma crença em algo, sendo vista, enfim, como um fato do espírito; ou sob um ponto de vista ético, 
indicando a honestidade, a retidão, o comportar-se escrupulosamente de uma pessoa de bem: não se trata de crer ou de não crer, mas de consciência pura, de honradez, de moralidade.

Ora, permite-se ao legislador ou, para dizê-lo com Bruns, é legislativamente possível aceitar a respeito da boa fé um ou outro ponto de vista. A lei pode estabelecer que aquele que receba um objeto sem a consciência de andar contra o direito, na crença de que não subsista, pois, alguma ofensa ao direito, possa usucapir. Mas também pode declarar que seja admitido a usucapir somente aquele que tenha uma convicção honesta, que tenha razões suficientes para presumir que a aquisição está em conformidade com o direito. No primeiro caso, teríamos, segundo Bruns, um ponto de vista psicológico, no segundo caso um ponto de vista ético. No primeiro, basta, portanto, o mero fato psicológico de crer ou não crer, nem se devendo levar em conta a escusabilidade do erro. No segundo, deve-se determinar, com o critério de princípios ético-jurídicos ${ }^{4}$, até onde chegava o dever de refletir sobre todas as circunstâncias, e, por isso, sobre que condições a crença e o erro devem ser vistos como escusáveis. Vê-se que o ponto de vista ético deveria implicar uma concepção absolutamente positiva da bona fides. Ora, Bruns acrescenta, a legislação romana seguiu, no conceito da bona fides, o princípio ético. Isso já é manifesto nas próprias expressões: fides, bona fides indicam conceitos extremamente morais: em sentido ético empregam a palavra Cícero e todos os antigos, e foi somente por causa do cristianismo e do direito canônico que a palavra fides assumiu o significado de crença. Não é "Glaube" o significado fundamental dela, mas "Treue", e é mister, portanto, esquivar-se da expressão "gute Glaube", que confunde os conceitos.

Bruns procede logo a demonstrar, de um ponto de vista mais intrínseco e jurídico, sua asserção. E em um primeiro momento com uma indução geral. Contrariamente a Wächter, ele reputa a bona fides idêntica em todas as relações jurídicas: assim, a bona fides

\footnotetext{
${ }^{4}$ No parecer [de Bruns]: ético-jurídico-comerciais.

${ }^{5}$ N. do T.: Glaube, em alemão significa fé, crença, convicção. Por sua vez, Treue é palavra traduzível como lealdade. Gute Glaube seria traduzida ao pé da letra como boa fé. Bruns critica o emprego da expressão tedesca gute Glaube precisamente por ser contrário a uma concepção psicológica da boa fé (a boa fé como crença) e por ser defensor da concepção ética de boa fé, compreendida como lealdade de conduta em relação à outra parte. Impossível não ver nesta posição a proximidade com o conceito de boa fé objetiva.
} 
contratual é idêntica à bona fides na usucapião. Ora, em todas as relações contratuais, ela é o contraponto natural do dolus e denota, portanto, um conceito ético.

Em seguida, traz uma série de textos concernentes à usucapião (L. 7 § 6 L. 8 D. Pro empt. 41,4 ; L. 1 C. Si vend. pign. 8, 29(30); L. 3 ; 4 ibid.; Fr. Vat. 1 ; L. 5 § 2, 5 D. De a. et c. tut. $26,8)$ nos quais, em seu ponto de vista, a boa fé não pode significar crença, porque o comprador adquire efetivamente do proprietário ou de pessoa autorizada, mandatário, credor pignoratício, tutor. Outros textos, pelo contrário, demonstram-nos que se está de boa fé, embora se saiba que não se adquire do proprietário (L. 28 D. De nox, act. 9, 4; L. 5 pr. D. Pro der. 41, 7). Um valor especial Bruns atribui depois a algumas palavras da L. 7 § 2 D. Pro empt. 41, 4: "ou sabe (o escravo que não lhe foi concedido o pecúlio) ou deve sabêlo", ao exame dos quais dedica um inteiro parágrafo.

Ora, dado que a boa fé no direito romano é concebida sob um ponto de vista ético, seguese, segundo Bruns, que o erro inescusável destrói a bona fides e, portanto, impede a usucapião. Por outro lado, a tendência do direito romano não é de facilitar a usucapião, mas de restringi-la; fato este que se deve ter presente na pesquisa e no juízo acerca de seus princípios. Já Gaio (II, 49) dissera que, em relação às coisas móveis, “não facilmente cabe a usucapião ao possuidor de boa fé" 7 , e ainda Justiniano lamenta contra a usucapião que "[se alguém possuía de boa fé, por dois anos, bens alheios, mas itálicos,] eram excluídos os míseros proprietários dos bens e não se lhes reservava nenhum auxílio" ${ }^{8}$ (L. un. Cod. De usuc. transf. 7, 31) e reputa urgente que as "inhumanae angustiae", a "compendiosa iactura", os "iura nocentia" da usucapião sejam ainda mais limitados: também nas Novelas ele adicionou novas limitações.

Para combater as induções contrárias que Wächter retirara da teoria do erro, Bruns afirma desde o começo de seu escrito que a distinção de Wächter não está de acordo com aquela de Savigny entre erro próprio e impróprio, que ela não constitui qualquer antítese brusca; e isso lhe basta.

\footnotetext{
${ }^{6}$ N. do T.: "aut scit (servus peculium sibi concessum non esse) aut scire debet".

${ }^{7}$ N. do T.: "non facile procedit ut bonae fidei possessori usucapio contingat".

${ }^{8}$ N. do T.: "[Sed et si quis res alienas, italicas tamen, bona fide possidebat per biennium,] miseri rerum domini excludebantur et nullum eis reservabatur auxilium".
} 
4. Quase intermediária entre as duas, embora mais próxima em substância à doutrina de Wächter, é a opinião de Pernice. ${ }^{9}$ Como Wächter, ele se declara contrário à equiparação da bona fides nas relações reais e nas relações obrigacionais; haveria, ao contrário, uma antítese entre as duas espécies de boa fé. E, sobre a bona fides nas relações reais, principia observando que as fontes não nos devolvem qualquer imagem clara naqueles pontos que são precisamente objeto de nosso exame. De qualquer modo, é falso que fides jamais signifique crença (Glaube); assaz duvidosa é a equiparação de fîdes e bona fides. Vindo, porém, a indagar se a bona fides constitui uma mera convicção, ou se também acolhe em si um elemento moral, Pernice distingue nela efetivamente dois elementos, a ciência e a moralidade, o elemento intelectual e o elemento moral. Reconhece ainda que não é a ciência a impedir os efeitos jurídicos, mas sim a imoralidade ínsita nela. Aduz em prova disto aqueles textos, nos quais a ciência de vícios no ato de aquisição não é obstáculo à usucapião: isso ocorre, assevera, porque, apesar daquela ciência, não há imoralidade na apreensão e na detenção da coisa. São o Fr. VAT 1 e a L. 28 D. De nox. act. 9, 4. Outra prova deste fato retira do L. 8 D. Pro empt. 41, 1, no qual, ainda que se adquira do proprietário, duvida-se da boa fé por causa do objetivo ilícito pelo qual o negócio foi concluído, da L. $13 \S 2$ D. De usurp. 41,3 e da L. 2 8 D. Pro empt. 41, 4.

Contudo, dado que a bona fides é constituída por dois elementos, ele julga natural que se queira investigar qual seja o elemento originário. E, em oposição a Bechmann, sustenta que, nos juristas mais antigos, esse elemento moral não desponta como um elemento essencial: que, frente ao estado real das coisas, o elemento subjetivo permanece na sombra, e onde aqueles [juristas] o vislumbraram, tal momento subjetivo não exprime a intencionalidade, mas a crença, ou seja, não expressa algo ético, mas algo de intelectual. Somente em Pompônio encontramos pela primeira vez destacado fora de medida o elemento subjetivo. Este predomínio do elemento intelectual, esta mirada exclusiva à consciência nos juristas romanos deduz-se, segundo Pernice, do conceito de bona fide servire, que não manifesta certamente uma idéia de moralidade, das numerosas vezes que a bona fides é definida como ignorância ou erro ou que a errônea suposição é empregada de modo a significar a boa fé,

\footnotetext{
${ }^{9}$ M. A. Labeo. Halle 1878, II, pág. 207-230.
} 
da circunstância, por fim, de que nenhum dos antigos juristas se expressa de modo a fazer ressaltar a imoralidade como elemento essencial.

Sobre a questão se para a boa fé se demanda a convicção positiva do próprio direito ou se basta a mera ausência de uma persuasão contrária, isto é, do ponto de vista prático, se uma dúvida qualquer sobre o próprio direito constitui má fé, Pernice decide que a dúvida certamente causa prejuízo à boa fé, e assim é obstáculo à usucapião, mas não aquela dúvida que seja fundada sobre a reflexão ou cautela do possuidor, mas sim tal dúvida produzida em circunstâncias concretas e demonstráveis. Que a dúvida não seja assaz indiferente retira-se da L. 8 § 1 D. Pro empt. 41, 4, da L. 4 pr. e da L. 14 ibid., da L. 26 D. De poss. 41,2 e da L. 17 C. De rei vind. 3, 32. Que deva ser fundada em circunstâncias concretas e demonstráveis pode-se induzir da L. 30 C. De r. v. 8, 44, mas se induz sobretudo da ordem da prova; já que a boa fé se presume, o adversário, para excluí-la, deve de fato produzir uma circunstância concreta.

Como se vê, em substância sobre este ponto que é reduzida a opinião de Wächter e de Windscheid a uma forma mais determinada.

Acerca da relação do erro com a bona fides, Pernice rejeita acima de tudo como não romana a doutrina do erro escusável ou inescusável: os romanos somente distinguem entre erro de fato e erro de direito e não remetem, em seu ponto de vista, este conceito a um princípio superior. Ora, o error iuris certamente impede a usucapião; mas que relação possua com a bona fides no pensamento dos jurisconsultos romanos não se chega a compreender, no estado atual de nossas fontes. Sobre este ponto, pois, não se alcança mais que um resultado absolutamente negativo.

5. Quanto a mim, aquilo que, em todos os aspectos, parece-me guia seguro para penetrar a essência da bona fides, para compreender os textos e dissipar as névoas em razão das quais se chega a desesperar de alcançar a meta - e a este ponto se chega por um escritor como Pernice -, é o pensamento de que a boa fé é um conceito ético, assumido pelo direito, mas precisamente um conceito não alterado em nada pelo direito que o assume, não forjado 
pela lei a seu arbítrio. É, como eu diria, uma boa fé naturalis, não civilis, aquela a que a lei se refere.

Isto posto, minha opinião sobre as três questões propostas é a seguinte:

I. A boa fé é um conceito ético, geral e igual em todas as relações. Seu pressuposto normal na possessio bonae fidei e, portanto, na usucapião, é o erro, isto é, um fato psicológico; raramente a ação ou o comportamento exterior do sujeito. Quando, de qualquer modo, concorrem ao mesmo tempo o momento ético e o momento psicológico, não é concebível um predomínio de um sobre o outro, como não é concebível um predomínio

entre causa e efeito.

II. A boa fé, inclusive quanto ao grau, é medida pelo senso ou moral da sociedade, que entende por boa fé a mera ausência de dolo ou má fé, e é deixada [a constatação de sua existência], nos casos individuais, à apreciação do juiz, partícipe e intérprete deste mutável e indefinível sentimento. O âmbito maior concedido à boa fé pelo direito poderá aumentar sua importância e tornar mais delicada a sua admissão, mas não significa exaltação do seu grau.

III. A escusabilidade do erro, quando o erro constitui o substrato da boa fé, não pode importar nem importa para o direito romano e para a boa fé em si e por si considerada. Somente por causas especiais e por uma especial evolução tal escusabilidade vem a constituir um requisito da usucapião em alguns casos; mas sua relação com a boa fé é meramente extrínseca, não orgânica, nem se criou em relação à posse ad usucapionem uma boa fé civil.

6. Se queremos prescindir, por um momento, da assunção da bona fides no direito como elemento de uma série de relações jurídicas, é certo que ela permanece, porém, como um conceito claramente ético e social e existente, vale dizer, também fora do direito. Estamos, pois, em um daqueles campos que, de modo particular, o direito e a moral, estas duas supremas normas sociais, possuem em comum, e em um daqueles campos em que a moral 
sobressai, porque o dominava sozinha um tempo e continua sempre a dominá-lo todo, enquanto que o direito o conquistou apenas em parte. ${ }^{10} \mathrm{O}$ próprio nome já é indicativo disto, caso fosse necessário um semelhante indicativo. A fides era, para o romano, aquilo que, para nós, são a honra e a virtude - honor e virtus têm valor bastante diferente, mais extrínseco e material -, e significava a mais austera observância do próprio dever nas relações com os próprios semelhantes: e a bona fides não é nada além da fides romana com a adição de um dos usuais epítetos que não acrescentam especificamente nada ao conceito. Não sei como e por que Pernice nega-se a reconhecer a identidade conceitual apresentada por Bruns entre fides e bona fides; e tampouco me parece que se possa negar, embora Pernice queira fazê-lo, que a fides de per se não significa jamais crença, entendida na linguagem verdadeiramente romana. Verdade e mentira são os pensamentos fundamentais que se referem à fé e à perfídia, mas não credulidade e incredulidade. “A boa fé... é verdade e constância nos acordos e promessas". ${ }^{11}$ Se este claro e constante significado da boa fé pode, de tal modo, ser perdido de vista raciocinando sobre a própria palavra, isto me persuade de que Bruns realmente tinha razão ao afirmar que a tradução alemã "gute Glaube" confunde as idéias. Nisto nós [os italianos] estamos em uma condição bem mais favorável: nossa palavra fede [fé, crença], é bem verdade, não conservou grande parte do sentido pleno da romana fides: prestar fede [acreditar] não é, certamente, o romano fidem praestare: a crença e também a credulidade assumiram, em muitas frases e modos de dizer, o posto da verdade e da honra e quase inverteram a relação que se pensa. Entretanto, aquele sentido antigo não se extraviou de todo ${ }^{12}$, e, especialmente nas palavras afins perfidia [perfídia], fedele [fiel], infedele [infiel], perdura, pode-se dizer, inalterado. A nossa expressão buona fede [boa fé], tanto na tradição dos juristas quanto na linguagem popular, conserva, pois, quase a mesma força da bona fides dos jurisconsultos romanos. Ora, tal conceito ético não parece haver sofrido qualquer transformação ao ser assumido pelo direito. Nem se fala jamais de uma bona fides civilis ou de uma antítese entre bona fides naturalis e civilis, nem se adiciona jamais, nas várias relações jurídicas em que a bona fides entra em campo, qualquer requisito que altere o seu conceito ético e popular. E se em todas as relações, nas quais o direito assume tal elemento moral, nada se lhe foi acrescentado, nem lhe foi dado nenhuma forma diferente da sua, é força inferir disso que, assim como é

\footnotetext{
${ }^{10}$ Recorde-se, para passagens similares, o instituto do fidei commissum.

${ }^{11}$ CIC. Off. I , 7. "Fides... dictorum conventorumque constantia et veritas".

${ }^{12}$ Principalmente na língua poética e naquela língua literária que sofre mais a influência clássica. Cfr. ainda modos comuns de dizer da língua florentino-italiana: stare alla fede, romper la fede data, etc.
} 
único o conceito moral, também único venha a ser o conceito jurídico, que não é distinto daquele.

Contudo, havendo já fixado que a bona fides é um conceito ético e social que o direito, sem dúvida, assume, conservando-lhe a essência inalterada e, assim, igual em todas as relações, é certo que nas diversas relações jurídicas o honesto comportamento significado pela bona fides deve-se referir a um objeto determinado e diferente. O dever abstrato e geral de não extrair vantagem do dano causado a outrem deve em cada relação desenvolver-se em algum dever concreto e particular. Ora, que importa a bona fides na usucapião? Esta se refere à tomada da posse da coisa e importa que, em relação a esta tomada da posse, o usucapiente se haja comportado como uma pessoa de bem. ${ }^{13}$

Ora, também em relação à tomada da posse, tal honesto comportamento se pode explicar de vários modos e nem sempre facilmente determináveis. Mas na bonae fidei possessio em sentido próprio, isto é, na única figura de usucapião que sobrevive no direito justinianeu, a usucapião em regra tem por pressuposto que se ignore um determinado momento de fato, por meio do qual a aquisição da posse vem lesar substancialmente a outrem: este momento, até o qual a iusta causa permanece inalterada, corresponde exclusivamente à propriedade ou ao direito de dispor da pessoa que a abandona ou abandona absolutamente a posse. Dado que, de fato, com a posse se lesa efetivamente o direito de um proprietário, e que não se pode reputar que este haja consentido com a lesão, para se estar de boa fé convém ignorar absolutamente esta circunstância, acreditar, antes de tudo, no contrário: ignorar que o alienante não é proprietário e, ao revés, reputá-lo como tal; considerá-lo mandatário e mandatário legítimo do proprietário; ignorar que não era proprietário aquele que abandonou a coisa, ou, em um ulterior alargamento da esfera da bona fides em detrimento da iusta causa, ignorar que o proprietário que aparentemente deu seu consentimento não é pessoa capaz ou não é capaz de agir sozinho. Pode-se dizer que, em tais hipóteses, nosso dever moral é de ignorar o verdadeiro e, assim, supor o falso. Ausência de uma justa representação das coisas, substituição por uma errônea representação, eis a condição do sujeito, se ele está de boa fé.

\footnotetext{
${ }^{13}$ Onde isto não é expresso pela iusta causa. Para mim, a iusta causa não tem ofício diverso e a bona fides, em qualquer que seja o momento, não faz nada além de de integrá-la.
} 
Mas tal condição é um estado psicológico do sujeito. A boa fé, conceito ético, e, desde que o direito o assume, também jurídico, implica, em regra, quanto à usucapião, antes um estado psicológico, um erro do sujeito, que uma determinada conduta prática sua. Dizer que a bona fides é um comportamento próprio de pessoas de bem é defini-la genericamente; querendo declarar-lhe, e, podendo fazê-lo, o conteúdo específico, não se pode prescindir, quanto à usucapião, do momento psicológico. E por que tal é, de ordinário, o substrato da bona fides, os romanos usam infinitas vezes, nas espécies individuais, expressões como: credere, putare, existimare, scire, scientia ou conscientia, ignorare, nescire.

Dado isto, estabelecer, como faz Bruns, uma verdadeira oposição entre duas concepções ou duas formas da boa fé, uma ética e a outra psicológica, entre as quais seria dada também faculdade ao legislador de escolher, parece-me propriamente um pensamento turvo e infeliz. Bruns compreende sua boa fé ética como uma boa fé mais rígida, mais elevada, e a psicológica como uma boa fé mais relaxada. Mas não são ambos conceitos éticos? E o que é isto senão a oposição entre dois estados ou graus de um conceito ético, um mais rigoroso, o outro mais brando? Será que o substrato psicológico desaparece no pretendido ponto de vista ético, que não é nada além do mais alto, do mais rígido ponto de vista ético? Pelo contrário: também neste se deverá admitir uma crença, um erro na mente do sujeito: naturalmente, a crença é antes mais segura, o erro mais firme; teremos um mais elevado grau de convicção, porque precisamente corresponde a um grau ético mais elevado. Pode-se fazer, ao menos em abstrato, a distinção de grau que deseja Bruns; mas os termos usados por ele para significá-la são absolutamente infelizes e perigosos no raciocínio. Ambos os graus são éticos: ambos são determinados, em regra, por um estado psicológico conforme ao mesmo grau.

É inclusive sobre a base deste equívoco de termos que Bruns raciocina a fim de demonstrar que os romanos conheceram e acolheram a sua boa fé ética. A fides é um conceito ético: a bona fides é oposta ao dolus, também este conceito ético. Já que não se nega que a boa fé seja, de qualquer modo, um conceito ético, tais argumentos caem por si mesmos: para evidenciar com a mesma medida romana - se também houver necessidade de recorrer aos romanos - que na usucapião o conceito ético tem base psicológica, basta recordar que nas espécies individualmente consideradas o estar ou não estar de boa fé quanto à usucapião 
exprime-se quase constantemente por meio de [expressões como] ignorar ou saber, acreditar ou duvidar.

Mas realmente Bruns também aduz em sustento de sua tese espécies individuais, nas quais, em sua visão, a boa fé não pode significar crença, porque o comprador realmente adquire do proprietário ou de pessoa autorizada e, não obstante isso, está de má fé. São a L. 7 § 6 D. Pro empt. 41, 4, a L. 1 Cod. Si vend. pign. 8, 29 (30) ; L. 3, 4 ibid.; FR. VAT. 1 ; L. 5 § 2, 5 D. De auct. et cons. tut. 26,8 .

Ora, no primeiro texto Juliano apresenta o caso de um mandatário que vende por trinta aquilo que teria podido vender por cem, precisamente para causar desprazer e dano ao mandante: "in hoc solum ut te damno adficeret" ("com o único objetivo de causar-te dano"); e, pois, acrescenta, se o comprador ignora o fato, ele sem dúvida usucapirá: "ignorante do fato o comprador, não cabe duvidar de que o comprador usucapirá com o transcurso do tempo; porque quando sabidamente se vendeu um fundo alheio a quem o ignora, tampouco se interrompe a posse longa" ${ }^{14} \mathrm{O}$ contrário ocorre se há colusão entre o comprador e o mandatário para comprar por baixo preço. "Mas se há colusão entre o comprador e o procurador, e aquele corrompeu a este com um prêmio, para comprar o bem por menos, não será tido como comprador de boa fé nem usucapirá pelo decurso do tempo; e se contra o proprietário que reclama o bem houver começado a utilizar a exceção de haver sido vendida a coisa por sua vontade, o proprietário terá a réplica útil de dolo". ${ }^{15}$

As leis do Codex tratam de um credor pignoratício que vendeu o fundo penhorado com "dolo malo" (L. 1) ou "contra bonam fidem" (L. 4), ou vendeu por somente vinte áureos *7 escravos que valiam bem mais, com o objetivo de favorecer de modo ilícito o comprador "per gratiam" (L. 3), e se diz que o devedor pode repetir os danos causados pelo credor pignoratício, e nos casos em que este não seja solvente, reclamar a coisa ao comprador, restituindo, porém, o preço (L. 3: mandará que os compradores restituam os escravos

\footnotetext{
${ }^{14}$ N. do T.: "ignorante emptore, dubitari non oportet, quin emptor longo tempore capiat; nam et cum sciens alienum fundum vendidit ignoranti, non interpellatur longa possessio".

${ }^{15} \mathrm{~N}$. do T.: "Quod si emptor cum procuratore collusit et eum praemio corrupit quo vilius mercaretur non intelligetur bonae fidei emptor nec longo tempore capiet; et si adversus petentem dominum uti coeperit exceptione rei voluntate eius venditae, replicationem doli utilem futuram" ${ }^{* 7}$ N. do T.: Áureo: moeda de ouro cunhada em Roma no período imperial.
} 
havendo recibido o preço). ${ }^{16}$ Não só não se fala da usucapião, mas tampouco se discute a respeito da boa fé do comprador, salvo na L. 4, em que se acrescenta que também este é responsável pelos danos, se houver participado da fraude: "se puderes provar que o comprador participou da fraude com o credor". ${ }^{17}$

O Fr. Vat. 1 é um célebre fragmento, que nos oferece a questão ventilada entre os antigos jurisconsultos sobre a compra de res mancipi da mulher, concluída conscientemente sem a auctoritas do tutor ou com a auctoritas de um falso tutor. Os veteres não a julgavam uma compra de boa fé; e assim sustentavam também Sabino e Cássio; Labeão declarou que o comprador possuía pro possessore; Próculo e Celso admitiram a posse pro emptore, mas não da coisa, mas sim da possessio que a mulher podia alienar sem a auctoritas do tutor: o efeito prático era de permitir ao comprador a aquisição dos frutos. Por fim, Juliano, com base em uma constitutio Rutiliana, reconhecia a usucapião, se o comprador tivesse pagado o preço, mas com o senão de que a mulher sempre podia interromper a usucapião oferecendo a restituição do preço.

Finalmente, na L. $5 \S 2 ; 5$ De auct. et cons. tut., diz-se simplesmente que o tutor, comprando coisa do pupilo por meio de um co-tutor ou do credor pignoratício, deve comprar de boa fé.

Mas em todas estas hipóteses tampouco nos afastamos do pressuposto normal da usucapião. O comprador não crê que o mandatário tenha mandato de trair seu mandatário e deixar-se corromper, que o ius distrahendi do credor pignoratício se estenda até ao ponto de vender "dolo malo", de vender antes do prazo ou favorecer ilicitamente alguém, não crê que a mulher (no direito antigo) ou o pupilo possam alienar sem a auctoritas do tutor ou que um tutor falso possa prestar indiferentemente o mesmo serviço. Ele vê e sabe que tais pessoas não dispõem da coisa em conformidade com aquele modo através do qual a lei civil e as leis sociais, dominantes também estas largamente em similares relações, estabelecem um poder para aquelas pessoas; e esta sua ciência precisamente o constitui em má fé. Assim expressam-se as fontes, ressaltando também ou deixando supor naturalmente que, em caso de ignorância, o comprador está de boa fé.

\footnotetext{
${ }^{16}$ N. do T.: (L. 3: iubebit (praeses) emptores recepto pretio restituere servos).

${ }^{17}$ N. do T.: "si fraudem eum participa cum credor potueris docere".
} 
Sem dúvida, em alguma destas hipóteses - e é possivelmente isto que desviou a Bruns -, pressuposto da bona fides, além do estado psicológico, pode ser também um certo comportamento exterior, uma certa ausência de imoralidade nos atos. O comprador não deve buscar corromper o mandatário, para haver a coisa a preço mais baixo; não deve angariar dolosamente o favor do credor pignoratício a fim de induzi-lo a lhe dar quase em liberalidade o objeto penhorado, em cuja alienação o credor faz ele mesmo, em substância, as vezes de procurador; o tutor não deve pôr-se de acordo com seu co-tutor ou com o credor pignoratício contra o pupilo. Por fim, quando o afrouxamento da tutela da mulher também tornou possível que, em seguida ao pagamento do preço, a usucapião também corresse em relação à coisa comprada conscientemente da mulher sine tutoris auctoritate, o comprador não deverá nunca, durante o período da usucapião, agir de modo a subtrair-se à eventual restituição do preço por parte da mulher; neste caso, a boa fé consistirá antes em um comportamento exterior, que se deverá conservar por todo o decurso da usucapião. Mas também de que vale tudo isso? Não se nega que o pressuposto da bona fides possa ser também um determinado comportamento em atos; ou melhor, foi neste sentido que no direito clássico o in bonis podia constituir uma possessio bonae fidei. Isto somente quer afirmar que a bona fides não pode prescindir de um pressuposto qualquer, em ato ou em pensamentos: e que também o pressuposto normal, aquele que sobressai e, portanto, mais se recorda, aquele pelo qual a possessio bonae fidei se restringiu, já no direito clássico, a significar mais propriamente a aquisição non a domino, é um anormal estado psicológico, um erro.

Também outros textos apresenta Bruns, nos quais, pelo contrário, sabe-se que se adquire de quem não é proprietário e, contudo, se está de boa fé. São a L. 28 D. De nox. act. 9,4 e a L. 5 pr. D. Pro der. 40,7. Mas também estes dois célebres fragmentos não expressam senão hipóteses em que o pressuposto da bona fides não é o erro, mas o comportamento exterior leal do possuidor. Aproximamo-nos da hipótese do Fr. Vat. 1; com efeito, também nos fragmentos em questão tal comportamento deverá ser conservado por todo o decurso da usucapião; se o verdadeiro proprietário oferecer a litis aestimatio ao que recebeu conscientemente a noxae deditio de quem era somente possuidor de boa fé, se o marido doador oferecer a restituição do preço àquele que comprou da mulher donatária, o comprador não pode furtar-se a receber e a usucapião cessa. Isto não é expresso 
verdadeiramente pela hipótese da L. 5 D. Pro der., mas parece-me certo que se deva subentender.

Mudando-se as partes, o mesmo raciocínio se pode repetir contra o predomínio do elemento psicológico sobre o ético admitido por Pernice. Entre os dois momentos poderá haver uma relação de equilíbrio, nunca de predomínio, e, em todo caso, ao crescer um o outro também será exaltado. Não sei, pois, como o próprio Pernice concilia, em seu pensamento, tal afirmada prevalência do elemento psicológico com a sua outra justíssima asserção de que não é a consciência que impede os efeitos jurídicos, mas sim a imoralidade ínsita nesta.

E, em concreto, de quais argumentos faz uso Pernice para demonstrar que os antigos jurisconsultos conferiam um maior peso ao elemento psicológico? Frente ao estado real das coisas, ele observa, o elemento subjetivo permanece na sombra. Pernice refere-se àqueles casos em que, não obstante parecer que se está diante de um vício, a usucapião corre, porque tal crença é falsa: falsa existimatio non nocet; plus est in re etc. Mas que quer dizer isto? Ali onde não há uma lesão real, não se vê nem a ética nem a psicologia: se não se considera a má fé de pura imaginação é por que a bona fides deve substituir elementos ausentes na iusta causa ${ }^{18}$. Pompônio, ao se ligar ainda à falsa existimatio (falsa opinião) de vícios inexistentes, ${ }^{10}$ não é que deseje primeiro exaltar o elemento subjetivo ou ético sobre o elemento psicológico; será que o elemento psicológico não é subjetivo também ele? Pompônio concede a um e a outro, à boa fé, enfim, uma esfera mais larga, ampliando-lhe o âmbito: o que corresponde ao esgotamento da iusta causa a que se inclinava o mesmo jurisconsulto.

Mas a bona fides é definida ou explicada infinitas vezes como ignorância ou erro! Seria outro, em geral, o pressuposto da bona fides? E qual é a maravilha que se indica pelo estado, pelo momento específico que ela pressupõe? Mas o erro do sujeito engendra um estado ético no mesmo. E também lá onde a ética parece estar de fora, onde a boa fé parece um conceito estranho a nós modernos, isto é, no bona fide servire, devemo-nos reportar às condições peculiares da sociedade romana. Falsos escravos, pessoas livres que se deixam

\footnotetext{
${ }^{18}$ Que não é um negócio de aquisição anterior, como sustenta Pernice (II, pág. 181), mas uma relação com o antigo possuidor que exprime ou deveria exprimir a ausência de lesão a outrem. Somente há, talvez, o legado entre os títulos de usucapião, que poderiam ser ao mesmo tempo também modo de aquisição. Mas isso não importa, porque não se olha este aspecto: para mim, a iusta causa mais nítida e sobressalente é a que confunde todas as outras teorias: a derelictio. ${ }^{10} \mathrm{Na}$ L. $32 \S 1$ D. De us. 41, 3.
} 
vender dolosamente em colusão com o vendedor, não foram espetáculo raro, se se tivesse que remediar semelhantes torpezas com graves medidas legislativas.

A imoralidade nunca foi destacada como o elemento essencial! Mas o que mais significa bona fides? O que mais significa dolus, sua autêntica antítese? A imoralidade é ínsita ao conceito genérico da bona fides, cujo conteúdo específico na usucapião normalmente é o erro; e onde há mais firme crença, erro menos evitável, lá também está maior moralidade e maior honestidade.

7. E vamos à segunda questão: qual é o grau da boa fé? Deve-se concebê-la positivamente ou negativamente como mera ausência de má fé? Eu também me reporto sobre este ponto ao pensamento fundamental: a boa fé é um momento oferecido pela ética social e não alterado pelo direito que o assume. Ela é, portanto, a boa fé normal, humana, mensurada pela prática diária da vida, pelo senso moral da sociedade e remetida de tempos em tempos à apreciação do juiz, partícipe e intérprete deste senso. Ora, na sociedade romana, como na nossa, ela não significa senão a mera ausência de dolo ou má fé; assim, a falsa crença, que é o seu substrato, deve ser uma crença média e tal que, em geral, possa bastar a mera ignorância. É esta a opinião mais branda e sustentada pela maioria; ainda que, por não se ter sempre diante de si o pensamento fundamental, é entendida com alguma incerteza, a qual tentarei dissipar.

A opinião mais radical é representada principalmente por Bruns. Toda sua batalha sobre a boa fé ética e a boa fé psicológica, todo o esforço para demonstrar que o conceito romano é a boa fé ética, tende precisamente a estabelecer que os romanos exigem o mais alto grau da boa fé, a convicção mais absoluta. Mas já que, como se vê, a antítese posta por Bruns encerra um equívoco essencial de termos, dado que a boa fé é um conceito ético - e não pode ser outra coisa -, não se segue disso que seja um conceito ético rigoroso e medido por um critério superior ao normal. Por isso, só me ocuparei de alguns argumentos, que são preferencialmente argumentos a favor de nossa tese. ${ }^{19}$

\footnotetext{
${ }^{19}$ Deixo de lado o argumento geral que Bruns desejaria extrair da tendência do direito romano a restringir, mais que facilitar, a usucapião. Realmente, para tal tendência, Bruns remonta a Justiniano: fato que (seja dito com toda reverência devida à mente e à memória de Bruns) se chamaria despertar-se um pouco tarde. Eu reconheço, contudo, tal espírito na última jurisprudência; mas isso não conduziu a imaginar uma boa fé diferente daquilo que ela é na vida social.
} 
Bruns deseja valer-se, para reforçar sua afirmação, também da bona fides contratual e traz uma série de textos a demonstrar que a bona fides é o contraponto natural do dolus. Ora, não sei que coisa impedia Wächter e agora impede Pernice de admitir a identidade geral da bona fides em todas as relações. Possivelmente Wächter estava muito preocupado com as diferenças específicas que derivavam das diversas aplicações do conceito e não teve frieza suficiente para refletir que esta natureza não somente deveria ser admitida, mas devia naturalmente lograr êxito contra a tese de Bruns. Não se nega que a boa fé seja um conceito ético: trata-se de provar que é um conceito ético rigorosíssimo: ora, precisamente por que a bona fides é sempre posta em antítese ao dolus que todos os textos citados por Bruns provam exatamente o contrário. Alguns, pois, são vivamente característicos: porque se se fala de negligentia ou culpa, o contraponto será a diligentia, mas jamais a bona fides; melhor dizendo, e isso vale como contraprova, declara-se mais vezes que se deve mais por meio da bona fides ou que não se deve nada por meio dessa. ${ }^{20} \mathrm{E}$ se em um célebre fragmento de Celso $^{21}$ fala-se de fides ("pois com fides [boa fé] não porá naquelas coisas menor diligência que em suas próprias coisas") em contraposição a um caso de culpa lata a assim chamada culpa em concreto - assim o é precisamente porque naquele texto se observa e se declara o princípio assaz verdadeiro "latiorem culpam dolum esse" ("O dolo é uma culpa em sentido mais amplo").

Apenas dois textos parecem verdadeiramente dar um pouco de base à tese aqui sustentada.

São eles: a L. 8 D. Pro empt. 41, 4 de Juliano e a L. 32 § 1 D. De us. 41, 3 de Pompônio.

No primeiro, Juliano apresenta o caso de alguém que compra escravos de outra pessoa, sabendo que o vendedor dissipará em seguida o dinheiro: "sabendo o vendedor que o dinheiro seria imediatamente dissipado". ${ }^{2223}$ É um comprador de boa fé? Apesar daquela circunstância, a ele não desconhecida, sustentava-se comumente que sim, e é essa, diz Juliano, a opinião mais justa. "De que modo, pois, pode-se considerar de ma fé aquele que comprou do proprietário?"*11 Mas acrescenta em seguida: “a não ser que não venha a

\footnotetext{
${ }^{20}$ Cf. Proculus L. 68, pr. D. De contr. empt. 18, 1: "existimo te in exigendo non solum bonam /idem, sed etiam diligentiam praestare debere, id est non solum ut a te dolus malus absit, se 1 etiam ut culpa". Paul. L. 4 D. De eo qui pro tut. 27, 5 "eandem fidem et dilìgentiam praestat (o protutore), quam tutor praestaret". PAULI Sent., I, 4, 1 : "et bonam /idem et exactam diligentiam... praestare debet (o negotiorum gestor)". Ulp., L. 10 pr. D. Mand. 17, 1: "nihil - amplius quam bonam fidem praestare oportet eum qui procurat".

${ }_{21}^{2}$ L. 32 D. Dep. 16, 3. "nec enim salva fide minorem quam in suis rebus etc."

${ }^{22}$ N. do T.: "cum sciret venditorem pecuniam statim consumpturum".

${ }^{23}$ N. do T.: "Quomodo enim mala fide emisse videtur qui a domino emit?"
} 
usucapir quem comprou os escravos de um luxurioso, que haveria de dar imediatamente o dinheiro a uma prostituta". ${ }^{24}$

Certamente aqui a discussão é toda sobre o valor ético do ato; mas precisamente por isto esta discussão não tem a ver com o grau da boa fé e da crença que lhe serve de substrato, mas sim com o âmbito da própria boa fé. Não se trata de estabelecer até que limite corra o dever de investigar e de saber; o ponto em questão é se aquilo que se sabe exclui a boa fé. E se supõe que o comprador saiba muito bem que o outro, de quem adquire, dissipará subitamente o dinheiro ou o dará a uma prostituta: se ele pudesse ter somente uma vaga suspeita disso, porque o estima um pouco esbanjador e mulherengo, não estaria de má fé. O ponto em questão é, pois, outro: deve-se considerar que não perpetra uma lesão, que não tira vantagem do dano alheio, quem contrai com um homem em condições de espírito de tal modo anormais (sabe-se qual consideração e também qual posição jurídica era conferida aos pródigos em direito romano), deve-se considerar que não ofenda a moral social, os boni mores, quem presta auxílio conscientemente a uma imoralidade?

No outro texto, Pompônio expõe o caso de alguém que creia falsamente que a lei lhe proíbe de usucapir e decide que realmente a usucapião não corre a seu favor. Sobre este fragmento, muito célebre e utilizado, voltaremos a propósito da influência do erro. Por agora, isso nos interessa por um dos motivos alternativamente dados à solução "ou porque não considera que possua de boa fé". ${ }^{* 13}$ A opinião de Pompônio é isolada nas fontes: em regra, a falsa crença de um vício inexistente não prejudica nem para a usucapião nem para a aquisição imediata, a existimatio (opinião) cede à substantia. Entretanto, também alhures Pompônio concede uma semelhante eficácia ao elemento subjetivo, ainda que esteja em contradição com a realidade. Mas isso significa que exalte o seu grau? Ele não faz nada além de ampliar sua esfera e domínio, exigindo-a também lá onde a lesão real não se comete. Sem dúvida, isso aumenta em muito a importância da boa fé e indica uma evolução - neste aspecto excessiva - correspondente a uma involução da iusta causa; sem dúvida, isso tornará inclusive a sua admissão mais difícil e a investigação mais delicada: mas sua essência e medida não são em nada tocadas.

\footnotetext{
${ }^{24}$ N. do T.: "nisi forte et is qui a luxurioso et protinus scorto daturo pecuniam servos emit non usucapiet." *13 N. do T.: "vel quia non bona fide videatur possidere".
} 
Por fim, contra a opinião de Bruns estão também os textos que examinaremos mais abaixo, em que a bona fides é reconhecida, apesar de que se incorra em erros bastante inescusáveis, e até mesmo no erro inescusável típico, o erro de direito.

Está claro a que consequiências conduz esta doutrina no lado prático, isto é, em relação às dúvidas que o possuidor possa nutrir acerca do próprio direito. Eu expressaria esta influência com uma fórmula ligeiramente diferente daquela de Windscheid e de Wächter e que também pode parecer uma curiosa petitio principii: a dúvida, para prejudicar, deve ser tal que exclua na consciência comum a boa fé. Em suma, estamos sempre neste ponto: a medida é a consciência comum, o intérprete é o juiz. Nem acredito que a esta simples resposta se possa fazer a reprovação que Pernice aduz contra Windscheid e Wächter de que ao arbítrio judicial é imposto um peso que este não poderá facilmente sustentar. Bem, se for convocado um chinês a julgar na Itália ou se for ressuscitado um caldeu, pode ser; mas julgar na sociedade em que se vive, com o critério de sentimentos sociais de que ele mesmo participa, é a coisa mais simples para o magistrado. O que pode ser delicado e difícil é ressaltar as circunstâncias de fato em que a dúvida pode nascer; mas é este um peso - e isto não refoge à Pernice - que incumbe mais à outra parte que ao magistrado. De todo modo, pesado ou leve que seja o peso a suportar, a lei o impôs ao magistrado, assumindo a bona fides no direito, e ninguém o pode retirar. Poderá o juiz errar: mas o que isso quer dizer? Quem alguma vez pretendeu um juiz infalível? Mas se pode estar seguro, repito, de que o juiz será, no fundo, menos falível ao decidir acerca da bona ou mala fides que acerca da existência de tanto outros fatos jurídicos.

8. À questão agora tratada sobre a concepção positiva ou negativa e sobre o grau da boa fé se sói conectar também a outra questão de sua relação com o erro, isto é, com a escusabilidade deste. Creio que o vislumbre de tal conexão seja uma ilusão, não rara nestas matérias sutis, e, de minha parte, não a admito: pelo motivo de que, qualquer que seja a opinião aceita sobre o grau da bona fides, não me parece que logicamente a escusabilidade ou a inescusabilidade do erro deva ter sobre essa qualquer influência: dado sempre - tudo retorna àquele pensamento fundamental - que a boa fé é um fato social e ético não alterado pelo direito. E o que ocorrerá com a bona fides (e inclusive quando for o grau mais alto e refinado de boa fé, o sentimento mais firme acerca do próprio direito) quando ela tenha por base um erro inescusável, um erro de direito, por exemplo? Dir-se-á talvez que aquela 
absoluta convicção não se pode admitir em caso de erro inescusável, que a boa fé, em suma, não existe? Mas neste caso confunde-se a escusabilidade do erro com a probabilidade de sua existência: duas coisas que procedem, é verdade, pari passu em geral, mas que, de qualquer forma, são duas coisas e nada veda que às vezes se separem. Ou se dirá que a boa fé torna-se má fé porque é tratada como tal se o erro sobre que se apóia é inescusável? Torna-se para quem? Para o direito. Ora, mas o direito possui uma boa fé com pressupostos seus especiais, a boa fé jurídica não é idêntica à boa fé ética.

Como se vê, sou em geral da opinião de Wächter: o erro que é pressuposto da boa fé é um erro impróprio, sinal de reconhecimento de que a vontade (no caso, a vontade de lesar a outrem) não existe e, portanto, as conseqüências não derivam do erro, mas da ausência de vontade. E nada demonstra melhor a inutilidade da opinião adversária como a confusão em que se envolve o seu mais ilustre e galhardo fautor, Bruns, na crítica que, sobre este ponto, direciona contra Wächter. Vimos que objeta contra Wächter o fato de a distinção deste (entre erro que é motivo determinante e erro que é sinal de reconhecimento) não se coadunar com aquela de Savigny entre erro próprio e impróprio. Mas por qual motivo? Bruns não o diz: ele não vai além de confrontá-la com aquela de Savigny, explicando que esta significa erro em um fato por si eficaz e erro em um fato já ineficaz. ${ }^{25}$ Parece que ele foi induzido a afirmar tal divergência puramente por uma visão assaz turva e por uma falsa análise dos conceitos e das relações: e é propriamente uma lástima que uma mente como Bruns se haja fixado em torno de tal visão. Percebo isto a partir da crítica que ele faz à distinção de Wächter, independentemente de sua pretendida discordância com Savigny, da qual o acusa: "Os conceitos de motivo determinante e sinal de reconhecimento não constituem qualquer antítese definitiva e, na maior parte dos atos, podem ser empregados um ao lado do outro. Se, por exemplo, o comprador erroneamente acredita que o vendedor é o proprietário da coisa, este erro é para ele motivo determinante, já que, sem tal erro, não teria comprado daquele vendedor; mas é [também] sinal de reconhecimento, vez que, por esse [erro], é claro que ele não quis cometer qualquer injustiça”. ${ }^{26}$ Ora, tal crítica é realmente maravilhosa e confere ela mesma as armas para rebatê-la. Não há nada de estranho que um erro seja motivo determinante e sinal de reconhecimento ao mesmo tempo, quando se refira a dois diferentes momentos de um fato, que são para o direito como dois

\footnotetext{
${ }^{25}$ BRUNS, Bona fides, pág. 72-73.

${ }^{26}$ BRUNS, 1. c.
} 
diferentes fatos jurídicos. No exemplo aduzido por Bruns, o erro é, precisamente, erro no motivo determinante em relação ao negócio jurídico que se quis e se concluiu, e que, por outro modo, não se haveria porventura querido e concluído; é sinal de reconhecimento em relação ao ato ilícito, que não se quis e, pois, não se cometeu. A vontade de concluir o negócio jurídico esteve presente e, dado que não haja defeito em nenhum outro requisito, houve o negócio: o erro está no motivo e é o erro próprio de Savigny. A vontade de realizar uma ilícita apropriação não esteve presente e, pois, não há ato ilícito, mala fides ou dolo, a partir do momento em que falta um requisito essencial: nem o Estado poderia admitir as conseqüências dos atos ilícitos, se a lei não apagar dos atos ilícitos em gênero ou de alguns deles o requisito da vontade. Não é este o erro em fatos ineficazes de per se, inválidos por defeito da vontade, não é o erro impróprio de Savigny?

A crítica, pois, que Bruns dirige contra Wächter, além de ser falsa em si e fruto de uma confusão, deveria ser também dirigida contra Savigny, precisamente por que Wächter verdadeiramente não fez outra coisa senão assumir em peso a teoria de Savigny, mudandolhe os termos. Ou melhor, nem mesmo os termos; porque são de cunho savigniano também estes e tirados precisamente das definições que dá Savigny de um e de outro erro. Erro próprio, Savigny diz, é "o erro no motivo determinante da declaração de vontade"27; o erro impróprio é "o erro em que reconhecemos que a vontade que deveria ser deduzida da declaração na realidade não existe" ${ }^{28} \mathrm{E}$, finalmente, também ele, como Wächter, declara que a bona fides é um fato a cuja existência a escusabilidade ou inescusabilidade do erro é indiferente, precisamente porque se trata de erro impróprio. ${ }^{29}$

Extraordinária é, pois, a acusação que, depois de semelhante crítica, Bruns dirige contra a teoria de Wächter. Depois de haver declarado que os dois modos de considerar o erro devem conduzir a resultados opostos (e já se viu se são dois os modos de considerar o erro e se Savigny e Wächter chegam a resultados opostos!), acrescenta: "Uma coisa é oportuno notar neste ponto: como é inadmissível, a partir de conceitos tão abstratamente construídos, como aqueles do erro próprio e impróprio, tirar, por via de dedução a priori, o conteúdo de um conceito tão positivo como aquele da bona fides. Um raciocínio como aquele de Wächter - 'deve-se reconhecer, pois, que ele queria coisa conforme à justiça, que ele

\footnotetext{
${ }^{27}$ SAVIGNY, System, fr. III, fr. 112 (trad. it., Scialoja, pág. 138).

${ }^{28}$ SAVIGNY, System, III, p. 264 (trad. it., Scialoja, pág. 352).

${ }^{29}$ SAVIGNY, ibid. App. VIII, n. XV e n. XXII.
} 
acreditava estar em seu direito, que, pois, existe o fato da bona fides,' - é uma mera petitio principii, a qual pressupõe como estabelecido o conceito na bona fides que está para ser demonstrada". 30

Deduzir dos conceitos relativos ao erro o conceito da bona fides? Quem poderia haver sonhado isto? Para ter um sentido, aquelas estranhas palavras deveriam ser compreendidas como "deduzir dos conceitos relativos ao erro, da doutrina do erro, em uma palavra, a aplicação que à bona fides devem ter os princípios sobre a escusabilidade ou inescusabilidade daquele”. Mas então o que há de mais razoável e de mais lógico? Vê-se, porém, que Bruns está preocupado com a idéia de que o requisito da escusabilidade do erro seja inerente ao conceito de bona fides (o qual não se sabe por que deve ser mais positivo que aquele do erro) e de que não se possa ter bona fides de outro modo; e, em tal caso, não é propriamente Wächter, mas o próprio Bruns que se envolve inconscientemente em uma petitio principii. Wächter demonstrou bem, antes de concluir pela indiferença dos princípios acerca da escusabilidade, que a bona fides tem por base um erro impróprio, um erro que é sinal de reconhecimento: Bruns não cuida de provar que se trata, ao revés, de erro próprio, e que, portanto, aqueles princípios têm aplicação: disse simplesmente, já vimos com que grau de razão, que a teoria de Wächter é falsa e não coincide com a de Savigny e, abandonadas, pois, as perigosas abstrações do erro, das quais, em seu ponto de vista, não se pode concluir nada, aplica a escusabilidade do erro à bona fides. Oh, céus! Construir sobre a base de conceitos abstratos é perigoso, mas edificar sobre o nada e a partir do nada somente Deus o pode.

Concluindo, repetimos: se o direito romano não construiu uma boa fé jurídica ou civil, de nenhum modo é possível, logicamente, que o erro inescusável destrua a boa fé. Ora, tentei demonstrar em geral que o direito romano não fez outra coisa senão assumir a bona fides ética e social, sem alterar-lhe propriamente o caráter e os pressupostos; e confirmei esta tese em cada uma das questões positivas anteriormente tratadas. A última comprovação disso será fornecida precisamente pela discussão da última questão. Passamos com isso a demonstrar como os próprios romanos não reconheceram qualquer relação da bona fides com os princípios da escusabilidade ou inescusabilidade do erro.

\footnotetext{
${ }^{30}$ BRUnS, Bona fides, p. 73-74
} 
Não temos textos sobre a bona fides nas relações contratuais; e não acredito que alguém tenha jamais pensado em excluí-la em caso de ignorância inescusável. A ignorância do direito poderá ser uma gravíssima culpa, mas não creio que seria um fato doloso. Certamente, de todo modo, o silêncio das fontes seria muito estranho em caso de que os princípios sobre a escusabilidade ou inescusabilidade do erro devessem ser aplicados à bona fides e ao dolus.

Mas temos textos que dizem respeito a algumas outras relações ainda mais análogas à relação do possuidor ad usucapionem. Acima de tudo, os seguintes sobre o furto: GAIO II, 50; $§$, 5, I. De us. II, 6; L. $36 \S 1$, D. De us. 41, 3; os quais podem ser vistos, em substância, como um só, porque o texto das Instituições de Justiniano é repetido em Gaio e o texto das Pandectas é tirado das Res cottidianae do próprio Gaio. Expõe-se o caso de um usufrutuário, que aliena o parto da escrava crendo que a ele pertencesse: "credens suum esse"; erro inescusável típico, erro de direito: apesar disso, o usufrutuário não comete furto, porque não está de mala fides.

Mais interessante, por que a questão é tratada ex professo e por que a relação é precisamente a bonae fidei ou malae fidei possessio, somente por seus efeitos outros, é o texto relativo à hereditatis petitio, a L. 25 § 6 D. De her. pet. 5, 3 de Ulpiano:

“A expressão 'saber que não lhe pertencem' entender-se-á tão somente daquele que conhece o fato, ou também daquele que errou a respeito do direito, por reputar que o testamento havia sido feito devidamente, quando era nulo, ou que a herança deferia-se a ele preferentemente, quando em verdade precedia-lhe um outro ágnato? E não considero que este seja possuidor de ma fé, pois está isento de dolo, ainda que erre quanto ao direito". 31

Para livrar-se destes textos, Bruns passa a admitir um diferente conceito da bona fides não só com relação ao furto, mas também com relação à petitio hereditatis: justamente ele que acenou com um mesmo conceito da bona fides em todas as relações jurídicas. E isso não basta: já que, no $§ 4$ das Instituições, Justiniano acrescentou ao texto de Gaio o inciso "que

\footnotetext{
${ }^{31}$ N. do T.: "Scire ad se non pertinere utrum is tantummodo videtur, qui factum scit, an et is qui in iure erravit? Putavit enim recte factum testamentum, cum inutile erat; vel cum alius praecederet adgnatus sibi potius deferri. Et non puto hunc esse praedonem qui dolo ca-ret, quamvis in iure erret." * 15 N. do T.: "bona fide tamquam suam alienaverit".
} 
a houver alienado de boa fé como sendo sua" ${ }^{*} 15$, Bruns desejaria não estender aquela tão aberta "bona fides" à venda do parto concluída pelo usufrutuário, mas limitar o inciso à primeira hipótese, à venda de coisa dada em comodato ou alugada realizada pelo herdeiro.

Em matéria de usucapião, não temos nenhum texto relativamente à influência da escusabilidade do erro na bona fides em si. Temos efetivamente, contudo, uma série de textos - e destes nasce, pois, toda a disputa - que não reconhecem a usucapião em caso de erro inescusável, de erro de direito. São os seguintes:

"L. 4 D. De iuris et f. ign. 22. 6 Pomponius 1. III ad Sab. Nega-se que a ignorância do direito aproveite na usucapião, mas consta que aproveita a ignorância de fato." 32

“L. 31 pr. D. De us. et usuc. 41,3 PAulus (ou melhor, PomponiUs) 1. XXXII ad Sab. Nas usucapiões, o erro de direito nunca aproveita ao possuidor: e por isso disse Próculo que não se pode usucapir, pois há erro de direito, se por erro o tutor houvesse autorizado o pupilo a iniciar a venda, ou mesmo depois de transcorrido longo tempo após a venda."33

“L. $32 \S 1$ ibid. Pomponius 1. XXXII ad Sab. Se alguém não crê que lhe é lícito pelas leis usucapir aquilo que possui, deve-se dizer que, ainda que erre, não é, contudo, procedente

sua usucapião, seja por que não considera que possui de boa fé, seja por que não é procedente a usucapião para aquele que erra quanto ao direito." 34

“L. $2 \S 15$, D. Pro emptore 41, 4. Paulus 1. LIV ad Ed. Se sem a autoridade do tutor compro algo de um pupilo, que eu acreditava ser púbere, dizemos que a usucapião tem lugar, de modo que, neste caso, importe mais a realidade que a opinião; mas se soubesses que era pupilo, mas acreditasses que aos pupilos lhes era lícito administrar suas próprias

\footnotetext{
${ }^{32}$ N. do T.: "L. 4 D. De iuris et f. ign. 22. 6 Pomponius 1. III ad Sab. Iuris ignorantiam in usucapione negatur prodesse; facti vero ignorantiam prodesse constat".

${ }^{33}$ N. do T.: "L. 31 pr. D. De us. et usuc. 41,3 Paulus (ou melhor, Pomponius) 1. XXXII ad Sab. Nunquam in usucapionibus iuris error possidenti prodest: et ideo Proculus ait, si per errorem initio venditionis tutor pupillo auctor factus sit vel post longum tempus venditionis peractum (Mo. factus sit post tempus venditione peracta), usucapi non posse, quia iuris error est."

${ }^{34}$ N. do T.: L. $32 \S 1$ ibid. Pomponius 1 . XXXII ad Sab. Si quis id, quod possidet, non putat sibi per leges licere usucapere, dicendum est, etiamsi erret, non procedere tamen eius usucapionem, vel quia non bona fide videatur possidere vel qui in iure erranti non procedat usucapio.
} 
coisas sem a autoridade do tutor, não usucapirás a coisa, porque a ninguém aproveita o erro de direito." 35

Aos textos citados se sói também adicionar a L. 44 § 4 D. De us. 41, 3 de Papiniano, a L. 11 D. Pro empt. 41, 4 de Africano e a L. 5 D. Pro suo 41, 10 de Nerácio, nas quais se fala de uma non levis praesumptio, de uma iusta causa erroris ou de um probabilis error.

Eu tampouco creio, todavia, que frente a estas leis deva-se aceitar um conceito em tudo civil da bona fides quanto à usucapião, ou mesmo perder as esperanças de compreender o pensamento dos jurisconsultos romanos a respeito da relação do erro com a bona fides, como faz Pernice, que chega sobre este ponto a um resultado meramente negativo. Eu acredito que não se deva hesitar em desatar a questão como o nó górdio: advertindo que, sobre o terreno ideológico, tal modo de resolver as questões não é de ser rechaçado por si mesmo, já que freqüentemente o nó é visto onde não o há. A escusabilidade do erro tem influência sobre a usucapião, não sobre a bona fides: ela constitui um requisito independente da usucapião, que se soma então à bona fides - sempre, porém, sem alterar sua essência e sem condicionar, direi assim, sua existência jurídica - quando a bona fides substitui a iusta causa, vale dizer, no assim denominado título putativo. Diferentemente de Wächter, eu sustento a invasão progressiva daquelas sombras de iusta causa, que aparecem sob o nome genérico de título putativo, como uma verdadeira substituição progressiva da iusta causa pela bona fides: é a própria bona fides que é aplicada sempre mais largamente para integrar a iusta causa ${ }^{36}$ e tende a esgotá-la de todo e usurpar-lhe o posto. E ainda que tal divergência pareça assaz leve e praticamente sem importância, em verdade esta tem tal relevo dogmático que a mesma oferece-me, para a demonstração do assunto, um terreno amplíssimo e sólido, que Wächter não teve.

Em verdade, parece-me que uma demonstração decisiva de tal asserção se tira do exame atento dos textos referidos. Já no primeiro deles, L. 4 De iuris et f., de Pompônio, a

\footnotetext{
${ }^{35}$ N. do T.: L. $2 \S 15$, D. Pro emptore 41, 4. Paulus 1. LIV ad Ed. Si a pupillo emero sine tutoris auctoritate, quem puberem esse putem, dicimus usucapionem sequi, ut hic plus sit in re quam in existimatione (Cuiacius plus quam in re sit etc.): quodsi scias pupillum esse, putes tamen pupillis licere res suas sine tutoris auctoritate admi-nistrare non capies usu, quia iuris error nulli prodest.

${ }^{36}$ Para mim, em qualquer momento a bona fides somente tem função integrativa em relação à iusta causa usucapionis, vez que sustento que esta não significa propriamente o negócio de aquisição.
} 
escusabilidade ou inescusabilidade é posta em direta relação com a usucapião, não com a bona fides. No segundo, a L. 31 De us., o próprio Pompônio repete, como se crê $\hat{e}^{37}$, inclusive o mesmo princípio sempre em relação à usucapião e o exemplo que aduz é de um título putativo, a aquisição feita a um pupilo, na qual a intervenção da tutoris auctoritas não foi regular, por erro de direito. Ainda mais evidente neste aspecto é o outro fragmento, tão utilizado, de Pompônio, a L. $32 \S 1$ De usurp. : este jurisconsulto, negando a usucapião a quem, ainda que erroneamente, acredita que a lei não lhe permita usucapir, atribui isso a duas razões, a saber: ou por que ele não pode ser considerado como um possuidor de boa fé ou pelo motivo de que o erro de direito é obstáculo à usucapião. E deveria estar claro não somente que a inescusabilidade é de novo posta em relação exclusivamente com a usucapião, mas que, na segunda solução alternativa, é subentendido precisamente: "quamvis bona fide videatur possidere" (“considera que possui de boa fé").

Evidentíssimo, enfim, parece-me na L. $2 \S 15$, Pro empt., de Paulo, o paralelismo do error facti e do error iuris em relação à compra concluída com um pupilo. Em ambas as hipóteses apresentadas por Paulo, o comprador ignora o vício da iusta causa: na primeira, crê que o pupilo seja púbere, na segunda crê que os pupilos têm a faculdade de administrar as próprias coisas sem a auctoritas do tutor. Inegavelmente, o jurisconsulto admite, tanto num caso como no outro, a bona fides do comprador: somente no primeiro caso este usucapirá, no segundo não, "quia iuris error nulli prodest" ("pois o erro de direito a ninguém aproveita"). Para ele, é simplesmente este o motivo da decisão. De uma absurda exclusão da bona fides não se fala: e também aqui, note-se, o caso apresentado é sempre o de um título putativo.

E neste último aspecto, também onde não se dão casos especiais, como na L. 4 de iuris et f. ign. e na L. $32 \S 1$ de us., é de admitir-se que se queira referir ao título putativo: quem fala é Pompônio, um jurisconsulto que, seguindo as pisaduras de Nerácio, mostra-se fautor do título putativo. ${ }^{38} \mathrm{E}$ acrescente-se inclusive que a iusta causa erroris ou o probabilis error são

\footnotetext{
${ }^{37}$ É uma hipótese de Schulting fundada especialmente sobre a inscrição. Acolhe-a também Lenel na sua Palingenesi.

${ }^{38}$ Cfr. L. 3; L. 4 § 2 D. Pro suo 41, 10; L. 3 D. Pro her. 41, 52. Não contradizem a afirmatva a L. 4 D. Pro don. 41, 6 e a L. 29 D. De us. 41, 3 do próprio Pompônio. A usucapião ali é negada porque não há uma iusta causa suficiente nem mesmo na imaginação do sujeito, ou, se há, isto ocorre precisamente por efeito de um erro inescusável típico, o error iuris. 23
} 
expressões usadas nos textos de Nerácio e Africano, nos quais se reconhece, na mais larga medida, o título putativo, e a non levis praesumptio retorna em um caso em que a admite Papiniano. $^{23}$

Mas uma demonstração igualmente plena, vendo por outro lado da afirmativa, tem-se observando como procedem as coisas em relação à prova. A boa fé concernente ao direito do próprio autor ${ }^{39}$ se presume. É esta uma mera praesumptio hominis, não uma presunção legal. A razão pela qual se presume é a existência da iusta causa usucapionis; quem esteja em relação com pessoa que renuncia à coisa em seu favor tem suficiente razão para supor que esta pessoa tenha direito de dispor da coisa: no ordenamento imperfeito da propriedade romana, por conta daquela ausência singular de publicidade adequada a um Estado civil nas transmissões dos bens, não se pode exigir daquela pessoa que realize investigações especiais, ao certificar-se acerca da propriedade, além daquelas que se exijam de nós modernos a respeito das coisas móveis. Deste modo, a iusta causa vai, em realidade, até um certo indício que tenha função de justificar a boa fé, ainda que eu a creia uma função meramente acessória e eventual, pela qual não nasceu a iusta causa e à [configuração da] qual pode ser que não baste.

Mas quando a bona fides amplia seu domínio em detrimento da iusta causa e esta, atacada em sua essência, está a ponto de desvanecer ou até mesmo desvanece, então desaparece a presunção, porque desapareceu a razão da presunção: “Quem compra do pupilo”, diz Gaio, “deve provar que comprou com a autoridade do tutor sem que a lei o proíbisse". ${ }^{40}$ Deve-se então fazer prova de haver sido induzido em erro e de estar, pois, de boa fé: "Mas também se houver comprado sendo enganado pela autoridade de um falso tutor, entende-se que

\footnotetext{
Eu inclusive estaria tentado a acrescentar, como prova de minha afirmativa, também os passos das Instituições e das Res cottidianae de Gaio já citados: Gaio conclui que o usufrutuário comete furto, vendendo o parto da escrava, e, pois, o comprador pode usucapir: ele, porém, não pode usucapir. Ora, isso se explica facilmente dizendo que a ele falta a iusta causa usucapionis; o possuidor somente tem a mera bona fides. Mas Gaio parece-me que pertença à fila dos jurisconsultos muito conservadores em matéria de iusta causa usucapionis: em suas Instituições ele dela não fala, enquanto insiste constantemente sobre a bona fides, e Justiniano foi obrigado, seguindo Gaio, tanto a inserir, aqui e acolá, menção da iusta causa, quanto a acrescentar expressamente que o error falsae causae não é eficaz. Assim, eu creio que, para Gaio, se o erro não houvesse sido inescusável, este teria valido para justificar a usucapião também para o usufrutuário; mas sempre, se vê, a escusabilidade do erro sobrevém onde a iusta causa usucapionis desaparece de todo.

${ }^{39}$ Pode-se, em senso lato, considerar como próprio autor também o derelinquente.

${ }^{40}$ N. do T.: "Qui a pupillo emit probare debet tutore auctore lege non prohibente se emisse".
} 
comprou de boa fé". ${ }^{41}$ Ora, somente assim se exige que o usucapiente produza um fato concreto e sério para demonstrar sua boa fé. Sem dúvida também agora a sua boa fé não é destruída, se este fato positivo constitui um erro inescusável; mas, em compensação da iusta causa usucapionis, da qual se prescinde, é bastante razoável exigir que prove ainda uma iusta causa erroris.

Finalmente, se considerarmos a razão pela qual, na bonae fidei possessio, sob as demais relações, se prescinde da escusabilidade do erro, tal fato sobressai por meio de uma irresistível evidência. Se no furto, se na hereditatis petitio, se, acrescentamos inclusive, na aquisição dos frutos se prescinde da escusabilidade do erro, não pode não saltar aos olhos que, em todas estas relações, prescinde-se também da existência de uma verdadeira causa possidendi. Não falemos do furto; mas na própria hereditatis petitio é manifesto que se exige somente uma iusta causa existimandi para ser tratado como bonae fidei possessor. ${ }^{26}$ Ora, é impossível que entre as duas coisas não haja uma relação. O erro escusável, a iusta causa erroris, não se exige, porque este somente serve para substituir a iusta causa exaurida pela expansão da bona fides: aqui não se está a falar de iusta causa possidendi ou usucapionis e, portanto, tampouco se pretende uma iusta causa erroris.

${ }^{41}$ GAI L. $13 \S 2$. D. De Publ. 6, 2. "Sed et si deceptus falso tutore auctore emerit bona fide emisse videtur." 26 L. $20 \S 6$ e D. De h. p. 5, 3. Cfr. também L. 33 1, D. De us. 41, 3. 